\title{
SECOND SESSION
}

Held in the Main Auditorium

Vygyan Bhavan

Thursday, November 28, 1985, 10:00 to 12:00

Prof. R. Hanbury Brown, President in the Chair

The president declared the session open. Messages of good wishes were sent to absent former IAU Presidents and General Secretaries : V. Ambartsumian, A. Blaauw, G. Contopoulos, C. de Jager, L. Goldberg, J.H. Oort, L. Perek, D. Sadler, and B. Strömgren.

Before passing to the Agenda, the General Secretary, called upon by the President, established the quorum and found eight Adhering Countries not represented. The General Assembly then appointed G. Westerhout and O. Gingerich as Tellers.

\section{Report of the Finance Committee}

The General Secretary mentioned that copies of the financial report were in the hands of the official representatives and he thus invited the Chairperson of the Finance Committee, Prof. Ye Shu-hua, to read the report. Mrs. Ye reported as follows :

"The Finance Subcommittee has inspected the accounts of the IAU for the period 198284 and finds everything to be in order. We commend the General Secretary for making a fundamental advance in the modernization of the operations of the IAU Secretariat. We particularly applaud the installation of the IBM PC-XT for keeping the membership files, the installation of a telex machine for rapid communication and for revising the format and presentation of the fiscal accounts. The new format with explanatory notes is much clearer than the previous, which not only makes our job easier, but will also result in better fiscal management.

Along this line, we commend the General Secretary for continuing the effort started by his predecessor of maintaining as large a fraction of the IAU funds in interest bearing accounts as possible as well as taking advantage of favorable exchange rates whenever possible.

The Finance Subcommittee notes with satisfaction the low administrative costs of the IAU. We acknowledge the debt owed by the IAU and its members to the Officers, particularly the General Secretary and Assistant General Secretary, and to their institutions for the generous support which makes this possible.

We have examined both the proposed 1985 budget and the income and expenses for the first three quarters of the year. We have assured ourselves that the proposed budget will be met very closely, provided that all countries make their payments before the end of the year.

The Finance Subcommittee discussed the proposed 1986-1988 budget at some length. First, the proposed annual increase in the unit of contribution received particular attention. We are all aware that the costs of operating all organizations are rising nearly everywhere. In the IAU, the problem is compounded because the inflation rates differ in different countries and the exchange rates between countries also vary substantially. We endorse the approach taken by the General Secretary to form an average range of inflation around the world and then to set the increase of the unit at, slightly below, the low end of this range. The Committee realizes that such an approach will, from time to time, cause hardships for 
individual countries, but, over the course of time, such problems will average out. Therefore, realizing that we must continue to pay for the operations of the Union in the face of rising costs, we strongly endorse the proposed value of the unit of contribution.

As a corollary, we note that the payment of the 1985 contributions are running somewhat late. We urge that the adhering bodies take note of the importance to the IAU of receiving the contributions early in the year, and we urge all countries to pay their contributions as rapidly as possible. We gratefully thank those countries which actually pay in advance.

With regards to the actual budgets proposed for 1985-1988 we make the following comments. We note with enthusiasm the increasing emphasis upon the scientific programmes of the IAU, but this increase can only be obtained by squeezing the rest of the budget. We feel that we must carefully exarnine all the IAU programmes and put our resources into areas which are best, or uniquely, done by the IAU. The Finance Subcommittee unanimously agrees that the IAU is unique in fostering international exchange of, and contact between, astronomers. This is particularly important for developing countries, and those with foreign currency exchange problems where the IAU funding often acts as important seed money for maintaining international contacts.

Therefore, the Finance Committee recommends increasing the funding for the exchange of astronomers by 3 333.- SFr. per year, making up this amount by reducing support for the Regional Astronomy Meetings.

There are three resolutions pending before the General Assembly which call for increasing funding for support of services. The Finance Committee feels that such resolutions should be brought to the attention of the Executive Committee in time to receive careful attention when the draft budget is prepared. It seems unwise to increase the projected deficit.

As final comment, we note that the IAU membership is growing rapidly and the operations are becoming more complex. We feel that the Union should anticipate that the time will arise in the future when the General Secretary's job cannot be carried out effectively by one or two scientists who volunteer their time and services to the Union, and that the IAU Secretariat staff may have to be enlarged. In this case, the expenses will rise and additional sources of funding may have to be developed. We realize the important role that the IAU plays for astronomy, and it may be time to investigate the balance between the services rendered and the charges assessed. It is clear that many IAU functions cannot be self-supporting. Therefore, unless the adhering countries can afford to pay increased assessments, the IAU will have to look to those activities which produce income to carry the burden for the rest of the programmes.

We recommend that the Executive Committee looks into this matter in the near future in consultation with people experienced in the problems of funding non-profit, scientific societies. The IAU operations are now approaching in size and complexity those of a small corporation and deserve expert attention by experienced people."

The President thanks Prof. Ye and puts the report of the Finance Committee to the vote, each item separately.

1) The proposed budget 1985 was unanimously voted.

2) The increase of the unit of contribution was voted with 135 votes in favour, 15 against, and 7 abstentions.

3) The proposed budget 1986-1988 was voted by 151 votes in favour, none against, and 4 abstentions. 


\section{Financial Resolutions of the Executive Committee}

None.

\section{Resolutions submitted by the Executive Committee}

The following resolutions were submitted by the Executive Committee :

1) The XIXth General Assembly of the International Astronomical Union,

resolves that the name of Commission 51 shall henceforth be :

"Bioastronomy : Search for Extraterrestrial Life".

1) La XIXème Assemblée Générale de I'Union Astronomique Internationale,

décide que l'intitulé de la Commission 51 sera dorénavant :

"Bioastronomie : Recherche de la Vie dans l"Univers".

2) The XIXth General Assembly of the International Astronomical Union,

recalling Resolution 13 adopted by the International Council of Scientific Unions (ICSU) in Cambridge (September 1982) which expressed great concern about the refusal of exit visas to scientists, and noting that this is a serious obstacle to international cooperation in science,

resolves that the IAU, as an Adhering Body of ICSU, do its utmost, in the spirit of the aforementioned Resolution 13, to urge the responsible authorities in all inember countries to resolve as speedily as possible all cases referred to in that resolution.

2) L.a XIXème Assemblée Générale de l'Union Astronomique Internationale,

rappelant la Résolution 13 adoptée par le Conseil International des Unions Scientifiques (ICSU) à Cambridge (Septembre 1982), qui exprimait de sérieuses inquiétudes concernant le refus de visas de sortie à des scientifiques, et considérant que ceci est un obstacle serieux à la coopération scientifique internationale,

décide que I'UAI, en tant qu'Organisation Adhérente de l'ICSU, fasse tout son possible, dans l'esprit de la résolution 13 mentionnée ci-dessus, pour que les autorités responsables dans tous les pays meinbres résolvent aussi rapidement que possible tous les cas auxquels il est fait allusion dans cette résolution.

3) The XIXth General Assembly of the International Astronomical Union,

recalling Resolution 9 adopted by ICSU in Ottawa (1984) which expressed great concern about violations of ICSU's principles of universality, for example in the granting of entry visas to scientists wishing to attend scientific conferences, 
resolves that the IAU, as an Adhering Body to ICSU, do its Utmost, in the spirit of the aforementioned Resolution 9, to urge the responsible authorities in all countries to adhere to the guidelines given by the ICSU Standing Committee on the Free Circulation of Scientists and embodied in its publication "Advice to Organizers of International Scientific Meetings".

La XIXème Assemblée Générale de I'Union Astronomique Internationale,

rappelant la Résolution 9 adoptée par ICSU à Ottawa (1984), qui exprimait de sérieuses inquiétudes au sujet de la violation des principes d'ICSU sur l'universalité, par exemple, concernant la délivrance de visas d'entrée à des scientifiques désireux de participer à des conférences scientifiques,

décide que I'UAI, en tant qu'Organisation Adhérente de l'ICSU, fasse tout son possible, dans l'esprit de la Résolution 9 mentionnée ci-dessus, pour que les autorités responsables dans tous les pays, adoptent les directives du Comité Permanent de l'ICSU sur la Libre Circulation des Scientifiques, qui sont contenues dans sa publication "Conseils aux Organisateurs de Réunions Scientifiques Internationales".

were approved unanimously.

\section{Resolutions proposed by the Resolutions Committee}

At the request of the President, Dr. M. McCarthy, Chairman of the Resolutions Committee, reported about the work of the Committee. Nine resolutions were put forward by the Commissions (French translations are also included). Prior to reading the resolutions, Dr. McCarthy made the following announcement :

"Mes chers Collègues, Mesdames et Messieurs, je suis très content de vous présenter le texte des résolutions de la XIXème Assemblée Générale de l'Union Astronomique Internationale. Pour mes collègues membres du Comité des Résolutions, les Professeurs Kitamura et Morton et pour moi-même, ces travaux ont duré trois jours. Mais pour les Commissions et les membres de l'Union, ils représentent plusieurs mois et même plusieurs années d'efforts. Ces travaux - et particulièrement ceux qui traitent de l'établissement du temps atomique international et des effets néfastes et désastreux de l'interférence avec les observations radioastronomiques et optiques - sont vraiment un 'magna carta' et une 'rosetta stone' pour l'avenir de notre science. Je tiens à remercier par dessus tout Mesdames Elisabeth Völk et Danielle Lours, ainsi que la rédaction de notre journal anglais Mandakini, pour les efforts dignes d"Hercule qu'ils ont fournis. Maintenant, nous allons commencer.

Now in English : today in New England it is Thanksgiving day and we wish, my colleagues Professors Kitamura and Morton and I, to express our thanks to all of you in the Commissions of the Union for your works of months and years in preparing the material and ordering it for the resolutions. We owe a special debt of thanks to the officials of the General Secretariat. I wish to thank especially Elizabeth Völk and Danielle Lours who shared our work and concern and to the producers of Mandakini, their editors, typesetters and printers. The official text will be in Transactions IAU XIXB. Please note that Resolution C9 as printed in Mandakini is withdrawn from $L$ ist $C$ and has just been returned to $L$ ist $D$. Proper adjustments will be made before publication in French for Transactions XIXB." 


\section{Resolution B1 : Responsibility for Time}

The International Astronomical Union,

recalling 1) that the establishment of International Atomic Time (TAI) and of Coordinated Universal Time (UTC) is one of the present tasks of the Bureau International de I'Heure (BIH), and

2) that the IAU is the main parent scientific Union of the BIH, the other parent unions being the International Union of Geodesy and Geophysics (IUGG) and the International Union of Radio Science (URSI), and

considering

1) that the atomic time scales, originally used mainly in astronomy, have now a much wider use, including numerous and important technical and public applications,

2) that TAI is based solely on physical measurements independent of astronomy,

3) that there exists an inter-governmental organization of which the Bureau International des Poids et Mesures (BIPM) is the Executive Body in charge of the unification of measurement of the major physical quantities,

4) that UTC is based both on TAI and on the astronomical time scale designated as Universal Time (UT.1), and

5) the URSI recommendation A-1, 1984, relative to the transfer of TAI to the BIPM,

approves of TAl being taken over entirely by the Bureau International des Poids et Mesures, under the responsibility of the International Committee of Weights and Measures (CIPM) and of the General Conference of Weights and Measures,

recommends 1) that the function of determining and announcing the leap seconds of the UTC system, as well as the function of determining and announcing the $\triangle$ UTI corrections, be given to the new International Earth Rotation Service entrusted by the IAU and IUGG with the evaluation of the Earth rotation parameters, and

2) that a permanent committee, where the IAU will be represented, be created, under the sponsorship of CIPM in order to take care of the interest of TAI users, and

extends to the Paris Observatory its thanks for the service provided to the international community by supporting the $\mathrm{BIH}$.

\section{Résolution BI : Responsabilité de I'Heure}

L'Union Astronomique Internationale,

rappelant $\quad$ 1) que l'établissement du Temps Atomique International (TAI) et du Temps Universel Coordonné est une des tåches actuelles du Bureau International de l'Heure (BIH), et 
2) que I'UAI est la principale Union scientifique mère du $\mathrm{BIH}$, les autres unions apparentées étant l'Union Internationale de Géodésie et de Géophysique (UGGI) et l'Union Internationale des Sciences Radio (URSI), et

considérant

1) que les échelles de temps atomiques, originellement utilisées principalement en astronomie, ont maintenant acquis une diffusion plus large comprenant de nombreuses et importantes applications techniques et publiques,

2) que le TAI est basé uniquernent sur des mesures physiques indépendantes de l'astronomie,

3) qu'il existe une organisation inter-gouvernementale dont le Bureau International des Poids et Mesures (BIPM) est le Corps Exécutif, ayant la charge de l'unification de la mesure des quantités physiques importantes,

4) que I'UTC est basé à la fois sur le TAI et sur l'échelle de temps astronomique connue sous le nom de Temps Universel, (UT1), et

5) la recommandation de I'URSI A-1, 1984, relative au transfert du TAI au BIPM

approuve la prise en charge complète du TAI par le Bureau International des Poids et Mesures, sous la responsabilité du Comité International des Poids et Mesures (CIPM) et de la Conférence Générale des Poids et Mesures,

recommande

1) que la fonction de détermination et d'annonce des secondes intercalaires du système UTC, comme celle de déterminer et d'annoncer les corrections $\triangle U T l$ soient confiées, en plus de l'évaluation des paramètres de rotation de la Terre, au nouveau service international "Rotation de la Terre", à qui l'UAI et l'UGGI donnent leur entière confiance,

2) qu'un comité permanent, dans lequel I'UAI sera représentée, soit créé, sous le parrainage du CIPM, dans le but de prendre soin des intérêts des utilisateurs du TAI, et

adresse à l'Observatoire de Paris ses remerciements pour le service rendu à la communauté internationale par le support apporté au BIH.

\section{Resolution B2 : Reference Frames}

The International Astronomical Union,

recognizing the highly significant improvement in the determination of the orientation of the Earth in space as a consequence of the MERIT/COTES* programmes of observation and analysis, and

the importance for scientific research and operational purposes of regular earth-orientation monitoring and of the establishment and maintenance of a new Conventional Terrestrial Reference Frame, 
thanks all the organizations and individuals who have contributed to the development and implementation of the MERIT and COTES programmes and to the operations of the International Polar Motion Service (IPMS) and the Bureau International de l'Heure (BIH),

endorses the final report and recommendations of the MERIT and COTES Joint Working Groups,

decides 1) to establish in consultation with the IUGG a new International Earth Rotation Service within the Federation of Astronomical and Geophysical Services (FAGS) replacing both the IPMS and the BIH from 1988 January 1 , for monitoring earth rotation and for the maintenance of the Conventional Terrestrial Reference System,

2) to extend the MERIT/COTES programmes of observation, analysis, intercomparison and distribution of results until the new service is in operation,

3) to recommend that an optical astrometric network be maintained for the rapid determination of UTI for so long as this is recognized to be useful, and

4) to set up a Provisional Directing Board to submit recommendations on the terms of reference, structure and composition of the new service, and to serve as the steering committee for the extended MERIT/COTES programines, and

invites National Committees for Astronomy and for Geodesy and Geophysics to subrnit proposals for the hosting of individual components of the new service by national organisations and observatories, and

urges the participants in Project MERIT to continue to determine high-precision data on earth rotation and reference systems and to make the results available to the BIH until the new service is in operation.

${ }^{*}$ MERIT $=\quad$ A programme of international collaboration to monitor Earth-rotation and intercompare the techniques of observation and analysis.

${ }^{*}$ COTES $=\quad$ A programme of international collaboration to establish and maintain a new conventional terrestrial reference system.

${ }^{*}$ FAGS $=$ Federation of Astronomical and Geophysical Services.

${ }^{*}$ IPMS = International Polar Motion Service.

\section{Résolution $\mathrm{B2}$ : Systèmes de Référence}

L'Union Astronomique Internationale,

reconnaissant les améliorations très significatives apportées à la détermination de l'orientation de la Terre dans l'Espace, suite au programme MERIT/COTES* d'observation et d'analyse, ainsi que

l'importance pour la recherche scientifique et pour des buts opérationnels de la surveillance de l'orientation de la Terre et de l'établissement et du maintien à jour d'un système de référence conventionnel terrestre, 
réinercie toutes les organisations et les individus qui ont contribué au développement et à la mise en place des programmes MERIT et COTES et aux opérations du service du mouvernent du pôle $\left(\right.$ IPMS $^{*}$ ) ainsi que le Bureau International de l'Heure,

adopte le rapport final et les reco:nmandations des groupes de travail MERIT et COTES,

décide 1) d'établir, en consultation avec l'Union Internationale de Géodésie et de Géophysique (UGGI), un nouveau service international au sein de FAGS $^{*}$, pour la surveillance de la rotation terrestre et la mise à jour du système de référence conventionnel terrestre, devant remplacer à la fois IPMS et le BIH à partir du ler Janvier 1988,

2) d'élargir les programmes MERIT/COTES d'observations, d'analyse, d'inter-comparaison et de distribution des résultats jusqu'à ce que le nouveau service soit opérationnel,

3) de recommander qu'un réseau d'astrométrie optique soit maintenu pour la détermination rapide de UTl aussi longtemps que cela sera jugé ustile,

4) de former un Bureau Directeur Provisoire, chargé de soumettre des recommandations sur les termes de références, la structure et la composition du nouveau service, et de servir de Comité Directeur pour l'extension des programmes MERIT/COTES,

invite les Comités Nationaux d'Astronomie, de Géodésie et de Géophysique, à faire des propositions pour l'hébergement des composants individuels du nouveau service par des organisations nationales et/ou des observatoires, et

insiste pour que les participants du projet MERIT continuent de déterminer des données de haute précision sur la rotation de la Terre et sur les systèmes de référence, et en communiquent les résultats au BIH jusqu'à ce que le nouveau système soit opérationnel.

\section{Resolution B3 : CCIR * Actions}

The International Astronomical Union,

recalling the considerations (a) to (d) of IAU Resolution No. 3 passed at the XVIIth General Assembly in 1979 concerning harmful interference to radio astronomy observations, and

noting

a) that the IAU, URSI * and COSPAR * have collaborated over many years in the Inter-Union Commission on the Allocation of Frequencies for Radio Astronomy and Space Science (IUCAF) in obtaining such bands by international agreement,

b) that certain experiments have begun in which transinissions take place from space in one of these bands, and that these transmissions may interfere with observations of $\mathrm{OH}$ emission from Halley's Comet,

c) that proposals for revision of Recommendation 314 of the $\mathrm{CCIR}^{*}$, for consideration by its XVIth Plenary Assembly, reflect the interests of astronomers, and 
d) that additions to CCIR Reports 224 and 697, and a draft new Recommendation (DOC. 2/196) emphasize the concern of radio astronomers regarding the possible effects of spurious emissions from space stations, especially those which are geostationary,

resolves

1) that the documentation of Study Group 2 of the CCIR, regarding revisions to Recommendation 314, Reports 224 and 697 and draft Recommendation (Doc. 2/196) is welcomed by astronomers as contributions to the XVIth Plenary Assembly of CCIR, and

2) that in respect to draft Recommendation (Doc. 2/196), astronomers should heed the likely limitations on observations within $5^{\circ}$ of a geostationary satellite orbit from any single observatory, and of the need to reduce the side-lobe gains of their antennae to the greatest practicable extent, and

recommends in view of the particular danger of interference to radio astronomy from space-based radio transmissions, that all those concerned in the design of systerns requiring radio transmissions from space should consult with IUCAF at the planning stage to ensure that sensitive passive radio observations are not jeopardized in the future.

* CCIR = International Radio Consultative Committee

* URSI = Union Radio Scientifique Internationale

* COSPAR = Committee on Space Research

\section{Résolution B3 : Actions du CCIR *}

L'Union Astronomique Internationale,

rappelant les considérations (a) à (d) de la Résolution No. 3 votée à la XVIIème Assemblée Générale de l"UAI en 1979 concernant l'interférence nuisible sur des observations radioastronomiques, et,

notant a) que L'UAI, I'URSI (2) et le COSPAR (3) ont collaboré durant de nombreuses années au sein de la Commission Inter-Union pour l'Attribution des Fréquences pour la Radioastronomie et les sciences spatiales (IUCAF) à l'obtention, par accord international, de telles bandes,

b) que certaines expériences ont été entreprises dans lesquelles des transmissions ont lieu depuis l'espace dans une de ces bandes, et que ces transmissions peuvent interférer avec les observations de l'émission $\mathrm{OH}$ de la Comète de Halley,

c) que des propositions de révision de la Recommandation 314 du CCIR, dans le contexte de sa XVIème Assemblée Plénière, reflètent l'intérêt des astronomes,

d) que des additions aux rapports 224 et 697 du CCIR*, et un projet de nouvelle Recommandation (Doc. 2/196) soulignent le souci des radioastronomes en ce qui concerne les effets possibles d'émissions intempestives depuis des stations spatiales, en particulier les stations géostationnaires, 
décide que 1) la documentation du Groupe d'étude 2 du CCIR, concernant les révisions de la Recominandation 314, des rapports 224 et 697 et du projet de recommandation (DDC 2/196) est accueillie favorablement, par les astronomes, comme contribution à la XIXème Assernblée Plenière du CCIR,

2) en ce qui concerne le projet de Recommandation (Doc. 2/196), les astronomes devront veiller aux limitations probables sur les observations à moins de $5^{\circ}$ de l'orbite d'un satellite géostationnaire à partir de tout observatoire, et à la nécéssité de réduire les gains de lobe de leurs antennes au maximum des possibilités pratiques, et

recommande

pour parer au danger particulier d'interférence avec la radioastronomie des transinissions radio à partir des stations spatiales, tous ceux qui sont concernés par la définition de systèmes utilisant des transmissions radio depuis l'espace se mettent en contact avec I'IUCAF dès la phase de définition de leur projet afin de garantir que des observations radioastronomiques passives et sensibles ne soient pas cornpromises dans le fiutur.

\section{Resolution B4 : Radio Frequency Transmission from Space}

The International Astronomical Union,

considering a) that certain frequency bands in the range $1300-1800 \mathrm{MHz}$ are very important to the science of radio astronomy, in particular the allocated bands 1330-1427 MHz, 1610.6-1613.8 MHz, 1660-1670 MHz and 1718.81722.2 $\mathrm{MHz}$,

b) that radio astronomy observatories are particularly vulnerable to interference from transmitters located on aircraft and spacecraft,

c) that the frequency range $1300-1800 \mathrm{MHz}$ is also the object of considerable attention for satellite systems in a number of countries for navigation, position location, and communications,

d) that certain modulation methods are coming into more common usage in Space Radio Services, such as spread spectrum techniques which may cause interference to radio astronomy, not only in frequency bands adjacent to transmission bands, but also at frequencies far removed from bands allocated to space services,

e) that the International Telecommunications Union (ITU) World Administrative Radio Conference (WARC) for Mobile Services, which is scheduled for 1987, may allocate frequencies in the band 1300-1800 $\mathrm{MHz}$ in order to accomodate satellite services, and

f) that the Mobile Service WARC in 1987 and the WARC on the Use of the Geostationary-Satellite Orbit and the Planning of the Space Services Utilizing It, which is scheduled for 1988, may establish technical standards governing unwanted emissions from the transmitters in the space services, 
urges a) that administrations avoid, whenever practicable, planning space systems with transmitters on spacecraft or aircraft which operate in the frequency bands listed in consideration (a) above,

b) that administrations take into account the current allocations to the radio astronomy service and its vulnerability to air and space transmissions when preparing proposals for the 1987 WARC for the Mobile Services and the 1988 Space WARC,

c) that administrations devise and adopt technical standards governing unwanted transmissions from transmitters in the space services both nationally and through the Radio Regulations of the UTI, and

d) that administrations coordinate those satellite systems which may impact radio astronomy through the Interunion Commission on the Allocation of Frequencies for Radio Astronomy and Space Science (IUCAF) with sufficient lead time in the planning phase for an effective exchange of concerns to take place.

IUCAF * = Inter-Union Commission on Frequency Allocations for Radio Astronomy and Space Science

Résolution B4 : Transmissions Radio-électriques à partir de l'Espace

L'Union Astronomique Internationale,

considérant a) que certaines bandes de fréquences dans le domaine 1300-1800 $\mathrm{MHz}$ sont très importantes pour la radioastronomie, en particulier les bandes allouées 1330-1427 MHz, 1610,6-1613,8 MHz, 1660-1670 MHz et 1718,8$1722,2 \mathrm{MHz}$,

b) que les observatoires radioastronomiques sont particulièrement vulnérables aux interférences provoquées par les émissions issues d'avions ou de satellites,

c) que le domaine de fréquences $1300-1800 \mathrm{MHz}$ est aussi d'un intérêt considérable pour les systèmes de satellites dans nombre de pays pour la navigation, la localisation de la position, et les communications,

d) que certaines techniques de modulation sont de plus en plus couramment employées dans les services de radio spatiale, telles par exemple les techniques de "spread spectrum", qui peuvent causer des interférences pour la radioastronomie, non seulement dans des bandes de fréquences adjacentes aux bandes de transmission, mais aussi à des fréquences très éloignées des bandes allouées aux services spatiaux,

e) que la Conférence Administrative Mondiale sur la Radio (WARC), pour les services mobiles de l'Union Internationale des Télécommunications qui est prévue pour 1987, pourra décider d'attribuer des fréquences dans la bande $1300-1800 \mathrm{MHz}$ en vue d'installer des services de satellites artificiels, et

f) que les Services Mobiles WARC en 1987 et le WARC prévu en 1988 pour l'Utilisation de l'Orbite Géostationnaire et la Planification des Services Spatiaux qui l'utilisent, pourra décider de l'établissement de standards 
techniques relatifs à des émissions non voulues à partir d'émetteurs dans des services spatiaux,

insiste pour a) que les administrations évitent, chaque fois qu'il est possible, de proposer des projets de systèmes spatiaux comprenant des érnetteurs sur satellites ou avions opérant dans les bandes de fréquences dont la liste figure ci-dessus (considération a),

b) que les administrations prennent en compte les allocations actuelles au service de la radioastronomie et sa vulnérabilité aux transmissions aériennes et spatiales lors de la préparation des propositions pour la WARC 1987 pour les Services Mobiles, et pour la WARC spatiale de 1988,

c) que, au plan national, ou à partir des règlements radio de l'UIT, les administrations mettent au point et adoptent les standards techniques régissant les émissions intempestives à partir d'émetteurs spatiaux, et

d) que les administrations coordonnent les systèmes satellisés qui peuvent interagir avec la radioastronomie, par l'intermédiaire de IUCAF* , en tenant compte d'un délai suffisant au niveau de la planification pour qu'un échange de vues puisse avoir lieu.

\section{Resolution B5 : VLBI Coordination}

The International Astronornical Union,

recognizing 1) that the well-established international collaboration in ground-based VLBI has resulted in high-angular-resolution radio inaging,

2) that ground-based VLBI images have demonstrated the need for even higher resolution which can be achieved by the combination of ground arrays and future space-based antennae,

3) that the feasibility of launching space-based VLBI elements into Earth orbit is under investigation by space agencies around the world,

4) that the full scientific benefits of VLBI will result only from observations obtained through the combined and simultaneous use of all space-based antennae with existing ground facilities, and

5) that COSPAR has established an Ad-Hoc Committee to examine the requirements for coordinated space and ground-based VLBI activities,

recommends that the appropriate national and international authorities concerned with space and ground-based VLBI make every effort to coordinate in a timely way the contributions to this important international programme.

* COSPAR = Committee on Space Research 
Résolution B5 : Coordination Relative à l'Interférométrie à Très Grande Base (VLBI)

L'Union Astronomique Internationale,

reconnaissant 1) que la collaboration internationale dans le domaine de la VLBI au sol conduit à de l'imagerie à haute résolution angulaire,

2) que les images VLBI au sol ont prouvé la nécessité d'une résolution encore plus grande qui peut être atteinte par la combinaison de réseaux d'observatoires au sol et de futures antennes placées dans l'espace,

3) que la faisabilité de placer sur orbite des éléments de VLBI est à l'étude dans différentes agences spatiales du monde,

4) que le maximum de retombées scientifiques du VLBI ne pourra résulter que d'observations à la fois combinées et simultanées de toutes les antennes en orbite avec les installations existant au sol,

5) que le COSPAR* a constitué un Comité ad hoc pour examiner les conditions nécessaires aux activités VLBI coordonnées entre l'espace et le sol,

recommande que les autorités compétentes nationales et internationales concernées par les VL_BI dans l'espace et au sol consacrent tous leurs efforts à coordonner les contributions à cet important programme international.

\section{Resolution B6 : Protection of Observatory Sites}

The International Astronomical Union,

reaffirms the importance of resolutions, adopted by previous General Assemblies, which relate to the protection of observatory sites and observing techniques, including

(1961) Resolutions Nos. 1 and 2, Transactions IAU XI,

(1964) Resolutions Nos. 3 and 5, Transactions IAU XIIB,

(1967) Resolution No. 2, Transactions IAU XIIIB,

(1970) Resolution No. 10, Transactions IAU XIVB,

(1976) Resolutions Nos. 8 and 9, Transactions IAU XVIB, and

(1979) Resolution No. 3, Transactions IAU XVIIB, and

requests that astronomers urge civil authorities to make all possible efforts to preserve the quality of observing conditions at the remaining excellent sites on this planet. 


\section{Résolution B6 : Protection des Sites d'Observatoires}

L'Union Astronomique Internationale, réaffirme l'importance des résolutions adoptées lors de précédentes Assemblées Générales, qui concernent la protection des sites d'observatoires et des techniques d'observation. Celles-ci comprennent :

(1961) les Résolutions Nos. 1 et 2, (Transactions IAU XI),

(1964) les Résolutions Nos. 3 et 5, (Transactions IAU XIIB),

(1967) la Résolution No. 2, (Transactions IAU XIIIB),

(1970) la Résolution No. 10, (Transactions IAU XIVB),

(1976) les Résolutions Nos. 8 et 9, (Transactions IAU XVIB), et

(1979) la Résolution No. 3, (Transactions IAU XVIIB),

et,

demande que les astronomes agissent auprès des autorités civiles afin que ces dernières fassent le maximurn d'efforts pour préserver la qualité des conditions d'observation dans les excellents sites restant sur cette planète.

\section{Resolution B7 : Danger of the Contamination of Space}

The International Astronomical Union,

noting with grave concern the dramatically increasing uses of space for scientific and other purposes and the accompanying contamination of space that adversely affects astronomical observations from the ground and from space,

re-affirms its previous resolutions bearing on the uses of space,

maintains that no group has the right to change the Earth's environment in any significant way without full international study and agreement, and

$\underline{\text { urges }}$

that all national representatives bring this concern to the notice of adhering organizations and space agencies in their countries.

\section{Résolution B7 : Danger de la Contamination de l'Espace}

L'Union Astronomique Internationale,

constatant avec de graves inquiétudes l'augmentation dramatique des utilisations de l'espace dans des buts scientifiques et autres et par là même la contamination de l'espace qui affecte dangereusement les observations astronomiques depuis le sol et l'espace,

réaffirme ses résolutions précédentes concernant les utilisations de l'espace, 
maintient qu'aucun groupe n'a le droit de changer l'environnement de la Terre en aucune façon sans qu'une étude internationale complète n'ait lieu, et qu'un accord en découle, et

insiste auprès de tous les représentants nationaux afin qu'ils fassent part de leur souci aux organisations adhérentes et aux agences spatiales dans leurs pays respectifs.

\section{Resolution B8 : Tycho's Observatories}

The International Astronomical Union,

noting with great satisfaction that action has been initiated in both Sweden and Denmark which aims at an inprovement of the state of the remains of Tycho Brahe's observatories on the Island of Ven, a site of unique significance in the history of astronomy,

urges the relevant authorities to make every possible effort to preserve the ruins and to keep the site as a whole in a condition worthy of its past.

\section{Résolution B8 : Les Observatoires de Tycho Brahe}

\section{L'Union Astronomique Internationale,}

constatant avec graride satisfaction qu'une procédure a été engagée en Suède et au Danemark pour la restauration des restes des observatoires de Tycho Brahe sur l'île de Ven, site d'une importance unique dans l'histoire de l'astronomie,

insiste

auprès des autorités compétentes afin qu'elles fassent un maximum d'efforts pour préserver les ruines et pour maintenir le site dans un état digne de son passé.

\section{Resolution B9 : Endorsement of Commission Resolutions}

The XIXth General Assembly of the International Astronomical Union,

having full confidence in its Commissions,

endorses the other Resolutions submitted by them to the Resolutions Committee for publication in the official languages of the Union, French and English, in Transactions IAU XIXB.

\section{Résolution B9 : Soutien des Résolutions des Commissions}

La XIXème Assemblée Générale de I"Union Astronomique Internationale,

accordant son entière confiance à ses Commissions,

souscrit aux autres résolutions qu'elles ont soumises au Comité des Résolutions, pour être publiées dans les deux langues officielles de l'Union, le français et l'anglais, dans les Transactions de l'UAI XIXB.

The full texts of the 14 Resolutions by IAU Commissions (Cl-C14) are as follows : 